\title{
Evidence for Sleep in Sharks and Rays: Behavioural, Physiological, and Evolutionary Considerations
}

\author{
Michael L. Kelly ${ }^{a-c}$ Shaun P. Collin ${ }^{b-d}$ Jan M. Hemmi ${ }^{a}$ b John A. Lesku ${ }^{d}$ \\ ${ }^{a}$ School of Biological Sciences, The University of Western Australia, Perth, WA, Australia; ${ }^{b}$ Oceans Institute, \\ The University of Western Australia, Perth, WA, Australia; ' ${ }^{\circ}$ oceans Graduate School, The University of Western \\ Australia, Perth, WA, Australia; ${ }^{d}$ School of Life Sciences, La Trobe University, Melbourne, VIC, Australia
}

\section{Keywords}

Buccal pumpers - Cartilaginous fishes - Elasmobranchs .

Electrophysiology · Ram ventilators · Unihemispheric sleep

\begin{abstract}
Sleep is widespread across the animal kingdom. However, most comparative sleep data exist for terrestrial vertebrates, with much less known about sleep in amphibians, bony fishes, and invertebrates. There is an absence of knowledge on sleep in cartilaginous fishes. Sharks and rays are amongst the earliest vertebrates, and may hold clues to the evolutionary history of sleep and sleep states found in more derived animals, such as mammals and birds. Here, we review the literature concerning activity patterns, sleep behaviour, and electrophysiological evidence for sleep in cartilaginous (and bony) fishes following an exhaustive literature search that found more than 80 relevant studies in laboratory and field environments. Evidence for sleep in sharks and rays that respire without swimming is preliminary; evidence for sleep in continuously swimming fishes is currently absent. We discuss ways in which the latter group might sleep concurrent with sustained movement, and conclude with suggestions for future studies in order to provide more comprehensive data on when, how, and why sharks and rays sleep.
\end{abstract}

(c) 2019 S. Karger AG, Basel

\section{KARGER}

(c) 2019 S. Karger AG, Basel

E-Mail karger@karger.com

www.karger.com/bbe

\section{Introduction}

Sleep is often a conspicuous behaviour, distinguishable from wakefulness by immobility and postural relaxation, and accompanied by reduced awareness of the local environment. This sleep-related reduced responsiveness can be reversed (to wakefulness) with sufficient stimulation. The propensity to sleep is influenced by the time-ofday (circadian regulation) and prior sleep-wake history. Circadian oscillators (e.g., pineal gland, eyes) are entrained by environmental cues, commonly natural lightdark cycles, to act as pacemakers for the adaptive timing of sleep and wakefulness [Kazimi and Cahill, 1999; Falcón et al., 2007]. Sleep is also homeostatically regulated with lost sleep recovered by sleeping longer and more deeply [Borbély, 1982; Tobler, 2011].

In addition to the behavioural correlates of sleep, sleep is also a brain state. Analysis of brain activity, recorded by the electroencephalogram (EEG), reveals multiple sleep states in mammals and birds, called non-rapid eye movement (non-REM) sleep and REM sleep. Non-REM sleep is associated with high-amplitude, EEG slow waves, while REM sleep is characterised by a wake-like pattern of lowamplitude, high-frequency activity. REM sleep is also associated with signs of reduced skeletal muscle tone, eye movements under closed eyelids, and increased cardiore- 
spiratory variability [Aserinsky and Kleitman, 1953; Jouvet et al., 1959; Siegel, 2016]. Unequivocal non-REM and REM sleep have yet to be identified outside of mammals and birds, although some other animals appear to engage in two sleep states, including reptiles [Shein-Idelson et al., 2016; Libourel et al., 2018], zebrafish [Leung et al., 2019], cuttlefish [Iglesias et al., 2019], and flies [van Alphen et al., 2013]. However, the homology of these states (if any) to those in birds and mammals is unclear.

\section{Elasmobranchs: Sharks, Rays, and Kin}

Sharks and rays are cartilaginous fishes and living representatives of the earliest jawed vertebrates [Compagno, 1999; Fuss et al., 2014]. They are members of the Elasmobranchii of which approximately 1,000 species are extant today. Fossil records from 450 million years ago suggest that their basic morphology has changed little since their evolutionary appearance [Budker, 1971]. They mostly inhabit marine (and occasionally freshwater) habitats. In contrast to their popular image as mindless killing machines, they have demonstrated cognitive capabilities to match those of other vertebrates [Graeber and Ebbesson, 1972; Hart et al., 2006; Lisney et al., 2012; Fuss et al., 2014].

The variable mechanisms for ventilation are typically used to separate sharks and rays into two physiological groups. In both groups, oxygen-rich water is forced over the gills for gas exchange. However, how this flow comes about differs between these two groups and is directly linked to metabolism and lifestyle. Sharks and rays that rely predominantly on buccal pumping, such as members of the Heterodontiformes and Rajiformes, facilitate respiration by lowering and raising the floor of the buccal cavity. Lowering the floor increases buccal volume and draws oxygenated water into the mouth. The floor is then raised while the mouth is closed, decreasing buccal volume, which pushes the fresh seawater over their gills. This mechanism is also used by many bony (teleost) fishes. By ventilating the gills in this manner, buccal pumping sharks and rays, generally benthic species, can remain stationary for extended periods of time [Roberts, 1978; Carlson and Parsons, 2001; Carlson et al., 2004].

Conversely, more active pelagic species, such as those found in the taxonomic orders Myliobatiformes and Carcharhiniformes (families Mobulidae, Carcharhinidae, and Sphyrnidae) use ram ventilation. That is, these animals maintain forward motion to push oxygenated water into the mouth and over the gills, making these animals obligate swimmers [Brown and Muir, 1970; Wardle,
1985; Carlson et al., 2004]. Some ram ventilating benthopelagic species, including members of the Lamniformes, Squaliformes, and Carcharhiniformes (families Odontaspididae, Squalidae, and Carcharhinidae) are capable of brief periods of inactivity, during which time buccal pumping takes over as the method of ventilation [Brett and Blackburn, 1978; Carlson et al., 2004; Barker et al., 2011; Tomita et al., 2018]. Similarly, more sedentary species, whose primary method of respiration is buccal pumping, may ram ventilate while swimming. These differences, and combinations, in respiration raise interesting questions about sleep in these animals. Notably, when and how do obligate ram ventilating sharks and rays sleep? To begin, we first establish what is known about sleep and circadian rhythms in bony fishes. We then provide a thorough review on the evidence for sleep in sharks and rays. By doing so, we identify the gaps in our understanding about sleep biology in these cartilaginous fishes. We end with a discussion of the hypothetical possibilities for the form sleep might take in sharks and rays, and suggest areas for future research.

\section{Sleep in Bony Fishes}

Before moving onto sharks and rays, there is value in a brief review of sleep in the other class of fully aquatic vertebrates, the bony fishes. Studies on sleep in bony fishes are few, and, for the most part, have relied on behavioural criteria to determine the presence or absence of sleep [Campbell and Tobler, 1984; Hartse, 2011; but see Leung et al., 2019]. More is known about sleep in zebrafish ( $D a-$ nio rerio) than any other teleost [Zhdanova, 2011]. Sleeping zebrafish do not swim, and instead stay immobile near the bottom, or top, of the aquarium. Like humans, zebrafish are diurnal and respond to extended periods of wakefulness by increasing sleep duration [Yokogawa et al., 2007; Sigurgeirsson et al., 2013; Singh et al., 2017; Pinheiro-da-Silva et al., 2018]. Sleep is also regulated by circadian mechanisms [Zhdanova et al., 2001]. Sleep behaviour is associated with reduced and irregular respiratory rates [Árnason et al., 2015]. A recent report has described two sleep states in young zebrafish [Leung et al. 2019]. The second state is associated with muscle atonia and increased heart rate variability, similar to that observed during REM sleep in mammals; however, unlike mammals, this state occurs in the absence of eye movements [Árnason et al., 2015; Leung et al., 2019]. Thus, the relationship between these states and mammalian and avian REM and non-REM sleep is unclear. Pharmaceuticals that promote, 
or inhibit, sleep in humans have similar effects on sleep in zebrafish [Zhdanova et al., 2001; Appelbaum et al., 2009; Sigurgeirsson et al., 2013; Leung et al., 2019], such that the neurochemical pathways regulating sleep appear to be conserved across these distantly related vertebrates.

Behavioural studies on several species of Bermuda reef fishes, and other freshwater fishes, reveal that these species also sleep. Tauber and Weitzman [1969] and Tauber [1974] report that blueheads (Thalassoma bifasciatum), Spanish hogfish (Bodianus rufus), and many species of wrasse (family Labridae) could be easily handled and lifted to the surface at night, perhaps owing to elevated arousal thresholds while sleeping. Sleep, at least in the form of a circadian rest-activity cycle, has also been observed in rainbow wrasse (Coris julis), with animals burying themselves in the sandy substrate, where they remain inactive from dusk till dawn [Videler et al., 1986]. Threespot wrasse (Halichoeres trimaculatus) maintain an endogenous circadian rhythm under a 12:12 h light:dark photoperiod and under constant darkness; sleep-like behaviour (such as decreased locomotor activity and respiratory rates) was induced with melatonin, a sleep-promoting hormone in other diurnal animals [Hur et al., 2012]. Sleep behaviours have been reported in parrot fishes (family Scaridae) with animals retiring under corals [Dubin and Baker, 1982] or secreting a mucus cocoon in which they remained inactive throughout the night [Starck and Davis, 1966]. Perch (Cichlasoma nigrofasciatum) [Tobler and Borbély, 1985], goldfish (Carassius auratus) [Tobler and Borbély, 1985; Iigo and Tabata, 1996], walleye (Stizostedion vitreum) [Ryder, 1977], brown bullhead (Ameiurus nebulosus) [Titkov, 1976], and banded knifefish (Gymnotus carapo) [Stopa and Hoshino, 1999] ostensibly were sleeping as they could be handled or touched on the tail without eliciting a response.

As eye movements during sleep are a behavioural correlate of REM sleep in mammals, birds, and perhaps lizards, some observations of eye movements during periods of sustained quiescence in Bermuda reef fish raise the possibility of a REM sleep-like state in bony fishes [Tauber and Weitzman, 1969]. Subsequent studies have failed to observe the same phenomenon however [Peyrethon and Dusan-Peyrethon, 1967; Shapiro and Hepburn, 1976]. A novel form of sleep behaviour has been reported in a group of reef fishes (Dascyllus marginatus, D. aruanus, and Chromis viridis) that spend the night in live, hard corals. These fish exhibit an unusual sleep-swimming behaviour characterised by an increased fin stroke frequency to ventilate the coral, while maintaining a stereotypic nocturnal posture [Goldshmid et al., 2004].

Sleep in Sharks and Rays
Early research into sightless, cave-dwelling species of fishes [Pavan, 1946] suggested that these animals might be sleepless as they show evidence of continuous swimming and lack activity-based circadian rhythmicity. More recent studies, however, contradict this idea. Specifically, while cavefish (Astyanax mexicanus) do sleep, they in fact sleep very little, relative to their surface-dwelling conspecifics [Zafar and Morgan, 1992; Duboué et al., 2011, 2012; Yoshizawa et al., 2015; Jaggard et al., 2017, 2018]. Since the transition from a surface-living to cave-dwelling existence has consistently been associated with a large reduction in sleep across several populations, this may suggest that cave-living causes a reduction in the need for sleep. Reduced sleep among populations might arise if less neurologically demanding forms of wakefulness in the simplified cave environment reduce that need. This could be somewhat akin to the local decreases in sleep intensity that have been observed in the human sensorimotor cortex [Huber et al., 2006] and pigeon hyperpallium [Lesku et al., 2011; Rattenborg et al., 2019] following brain disuse during prior wakefulness.

Due to the difficulties recording brain activity in water, very few studies have focused on the electrophysiological correlates of sleep behaviour in bony fishes [Hartse, 2011]. What information is available is limited and warrants replication. A study that focused on modulating brain activity using sound and light in tethered, awake codfish (Gadus morhua) found that EEG recordings from the midbrain were dominated by $8-13 \mathrm{~Hz}$ waves, which appeared as spindles $0.5-5 \mathrm{~s}$ in duration, a pattern that was most pronounced under dark and silent conditions, and suppressed under light and noisy conditions [Enger, 1957]. A study on tench (Tinca tinca) found no evidence of a distinctive electrophysiological pattern with sleep behaviour [Peyrethon and Dusan-Peyrethon, 1967]. Conversely, EEG spikes and slow waves from the mid- and forebrain were accompanied by cardiac arrhythmia in sleeping catfish (Ictalurus nebulosus) [Karmanova et al., 1981; Karmanova and Belich, 1983].

Clearly, more study is needed to characterise the brain activity correlates of sleep behaviour in bony fishes, and a recently developed method of measuring neural activity using fluorescence in young zebrafish is particularly promising [Leung et al., 2019]. The central nervous system of these transparent animals alternates between synchronous flashes of activity and periods of silence. Interestingly, a second sleep state was also observed in which a burst of neural activity propagates across the neuroaxis. Whether these sleep states are homologous to mammalian and avian non-REM and REM sleep is unclear. 


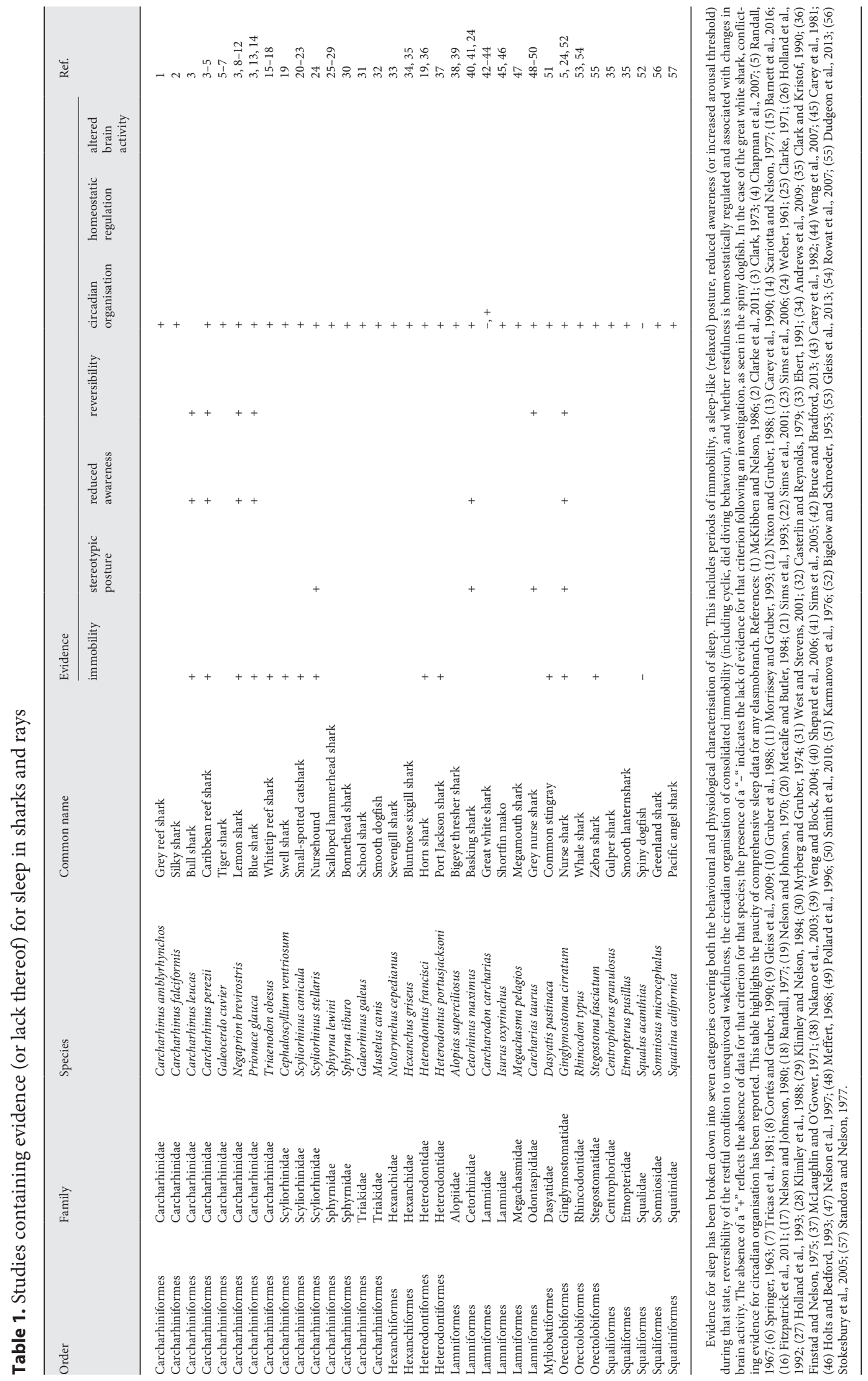



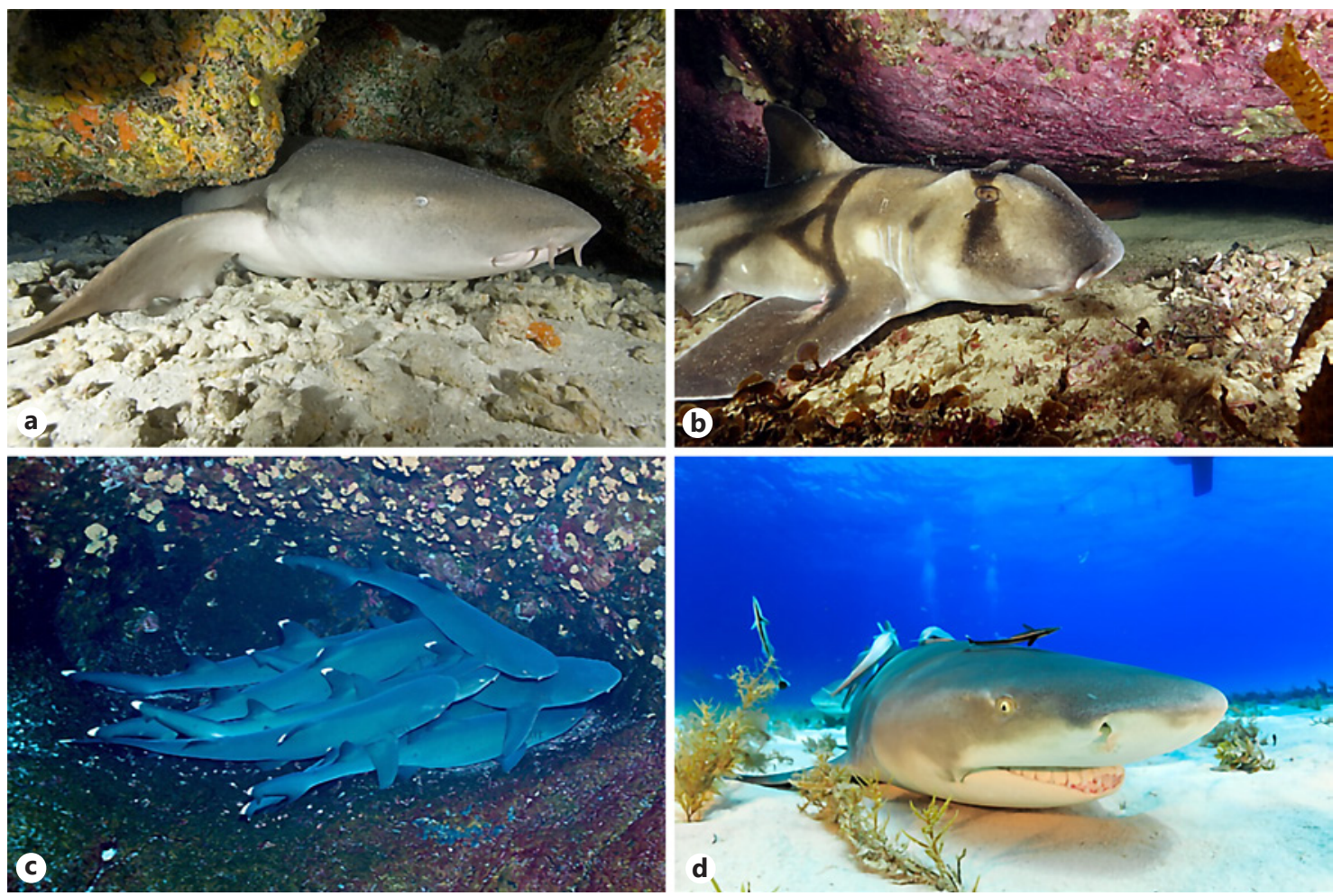

Fig. 1. Sleep-like behaviours in buccal pumping sharks. Species capable of ventilating the gills via buccal pumping can remain inactive for extended periods of time. A nurse shark (a) and a Port Jackson shark (b) resting in a rocky cave. c Whitetip reef sharks often rest in large, intraspecific congregations. d Lemon sharks are known to sit motionless on the sandy bottom for extended periods of time. Photographs by Yann Hubert/Shutterstock.com (a), Dirk van der Heide/Shutterstock.com (b), Janos Rautonen/Shutterstock.com (c), and Nicolas Voisinn/Shutterstock.com (d).

\section{Evidence for Sleep in Buccal Pumping Sharks and Rays}

Sharks and rays are inherently shy and elusive animals, often inhabiting hard-to-reach environments, which are rarely appropriate for sleep-based, experimental research [Heithaus et al., 2002; Papastamatiou et al., 2010]. Replicating the appropriate housing and husbandry to facilitate such studies in captivity also presents its own series of logistical complications. It is no surprise, therefore, that what information is available on this topic is anecdotal or incomplete (Table 1). Moreover, studies involve few animals, of limited phylogenetic diversity, often reaching conclusions only tangentially related to sleep.

With this preface in mind, a number of buccal pumping sharks have been observed either in the wild or in aquaria to have a sleep-like state, or at least a diel activity pattern. The eyelids of a captive nursehound (Scyliorhinus stellaris) appear to be half-closed during periods of sustained restfulness when the animal is propped up on its pectoral and tail fins, and its head rested against a rock or substrate [Weber, 1961]. A captive nurse shark (Ginglymostoma cirratum; Fig. 1) is able to spend extended periods of the 24-h day immobile in caves and becomes active only in the evening. Moreover, this species failed to react to scuba divers swimming nearby, at least until one diver pulled its tail, which evoked an escape response [Weber, 1961]. Such behaviours are consistent with observations by Randall [1967] who described wild nurse sharks as "sluggish," spending much of the daytime resting on the seafloor. Similar to nocturnal nurse sharks, two benthic species, the horn (Heterodontus francisci) and swell (Cephaloscyllium ventriosum) shark, seemingly sleep during much of the day in both the wild and in captivity [Nelson and Johnson, 1970] (Fig. 2). Night-time swimming and feeding begins with the onset of darkness; C. ventriosum maintains diel rhythmicity under constant light and constant dark photoperiodic conditions, whereas $H$. francisci does not. Subsequent work found that $H$. 
Fig. 2. Activity patterns of two buccal pumping sharks. Mean activity levels of horn and swell sharks recorded during 8 days of underwater observation at Santa Catalina Island, California. The activity levels of individual sharks were coded as: 0 - complete immobility; 1 - movement but no swimming; 2 - swimming along the bottom; 3 - swimming above the bottom. Although the absence of horn shark data during the day could be due to a lower incidence of daytime sightings, this was not the case for swell sharks, which were observed across the day and night. Reprinted from Nelson and Johnson [1970], with permission from The American Society of Ichthyologists and Herpetologists.

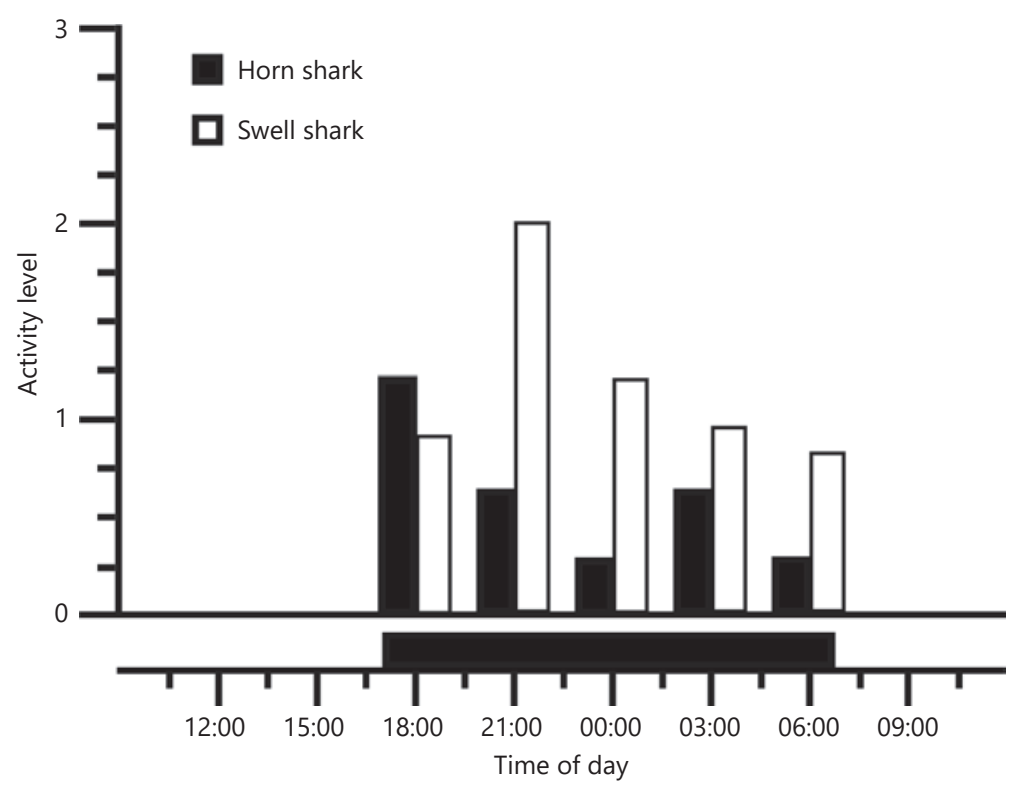

francisci maintains rhythmicity under constant dim light in captivity [Finstad and Nelson, 1975].

Many other sharks also apparently sleep during the day, and exhibit either crepuscular or nocturnal activity, including the small-spotted catshark (S. canicula) [Metcalfe and Butler, 1984; Sims et al., 1993, 2001, 2006], the Port Jackson (H. portusjacksoni) [McLaughlin and O'Gower, 1971], the zebra (Stegostoma fasciatum) [Dudgeon et al., 2013], the Pacific angel (Squatina californica) [Standora and Nelson, 1977], the Caribbean reef (Carcharhinus perezii), and whitetip reef shark (Triaenodon obesus) [Randall, 1967, 1977; Nelson and Johnson, 1980; Chapman et al., 2007; Fitzpatrick et al., 2011; Barnett et al., 2016]. An accelerometry and respirometry-based study found that wild whitetip reef sharks swim up to three times more at night and have a higher metabolic rate at night compared to that during the day under laboratory conditions [Whitney et al., 2007].

Increased activity and feeding rates have been observed in wild lemon sharks (Negaprion brevirostris), both during the night and twilight [Gruber et al., 1988; Cortés and Gruber, 1990; Morrissey and Gruber, 1993]; similarly, metabolic rate is higher in captive lemon sharks at night [Nixon and Gruber, 1988]. Using accelerometry, Gleiss et al. [2009] observed extended periods of resting behaviour in wild lemon sharks ( $N$. brevirostris). The common stingray (Dasyatis pastinaca) reduces its motor activity at night in captivity [Karmanova et al., 1976], which, to our knowledge, is the only report of a sleep behaviour in a ray. Lastly, we are not aware of any study looking at sleep homeostasis or sleep/wake recordings of brain activity in any cartilaginous fish (Table 1).

\section{Evidence for Sleep in Ram Ventilating Sharks and Rays}

Ram ventilating species show more modest (if any) changes in activity patterns. For example, the spiny dogfish (Squalus acanthias; Fig. 3) swims continuously in captivity, showing no obvious changes over a 24 -h period [Karmanova et al., 1976]. However, a circadian activity pattern does exist in some ram ventilating sharks. Basking sharks (Cetorhinus maximus) engage in cyclic diving migrations [Sims et al., 2005; Shepard et al., 2006]. In the wild, they can be observed idly gliding at the surface, basking in the sun (at times ventral-side-up), and can be touched without disturbance [Weber, 1961]. Similar suggestive evidence of increased arousal thresholds has also been reported in four species of wild requiem sharks ( $C$. leucas, C. perezii, Prionace glauca, N. brevirostris), two of which (the bull and blue shark) are thought to be obligate ram ventilators, found in an underwater cave off the coast of Mexico. These animals exhibit extended periods of in-
Kelly/Collin/Hemmi/Lesku 

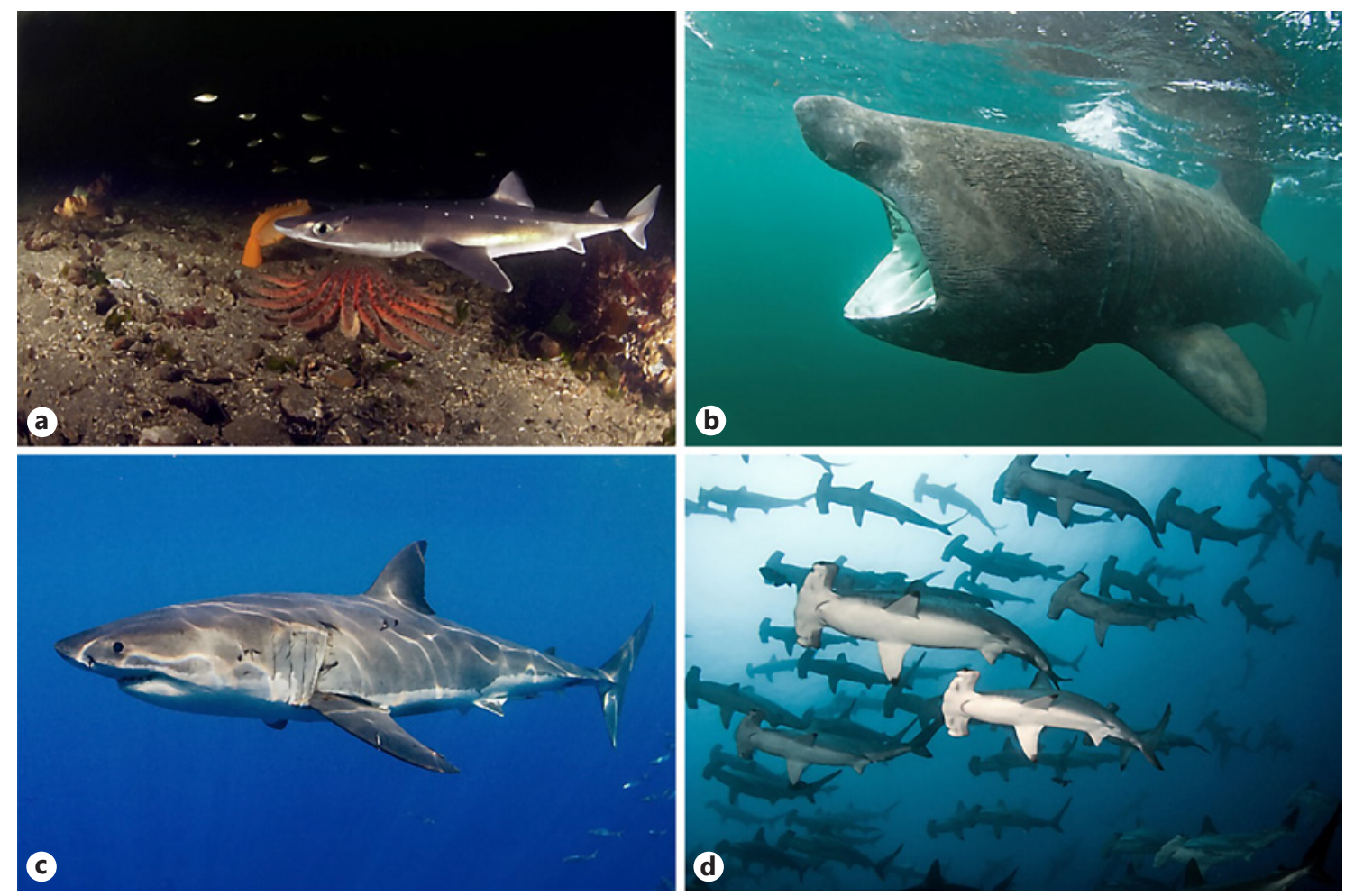

Fig. 3. Ram ventilating sharks. a A spiny dogfish shows no evidence of sleep-like behaviour in captivity, and instead swims without interruption. b The basking shark may have an elevated arousal threshold during periods of less intense swimming. c The great white shark, a known obligate constant swimmer, has shown conflicting evidence regarding any circadian rhythmicity in its activity patterns. d Scalloped hammerhead sharks, although never inactive, engage in cyclic, diurnal periods of foraging at night. Photographs by Greg Amptman/Shutterstock.com (a), Martin Prochazkacz/Shutterstock.com (b), Palomba/Shutterstock.com (c), and Tomas Kotouc/ Shutterstock.com (d).

activity and respond only after rough and excessive handling [Clark, 1973]. Milling behaviour (a form of low level activity, where sharks swim slowly within the same area with frequent directional changes) has regularly been observed in wild grey nurse sharks (C. taurus), with animals spending up to $85 \%$ of the daytime engaged in this behaviour, with more active swimming and foraging throughout the night [Meffert, 1968; Pollard et al., 1996; Smith et al., 2010]. Milling quickly transitions to rapid avoidance behaviour when approached by divers [Pollard et al., 1996; Smith et al., 2010]. Nocturnal activity patterns have been seen in laboratory studies of the smooth dogfish (Mustelus canis) [Casterlin and Reynolds, 1979], and in field studies of the sevengill shark (Notorynchus cepedianus) [Ebert, 1991], and the grey reef shark (C. amblyrhynchos) with the mean rate of movement doubling at night [McKibben and Nelson, 1986].

Although not compelling evidence of sleep, cyclic diel vertical migrations (DVMs) have been recorded in the shortfin mako (Isurus oxyrinchus) [Carey et al., 1981, 1990; Holts and Bedford, 1993], the blue (P. glauca) [Scariotta and Nelson, 1977; Carey et al., 1990], the megamouth (Megachasma pelagios) [Nelson et al., 1997], the school (Galeorhinus galeus) [West and Stevens, 2001], the bigeye thresher (Alopias superciliosus) [Nakano et al., 2003; Weng and Block, 2004], the Greenland (Somniosus microcephalus) [Stokesbury et al., 2005], the bluntnose sixgill (Hexanchus griseus) [Andrews et al., 2009], the whale (Rhincodon typus) [Rowat et al., 2007; Gleiss et al., 2013], and the tiger (Galeocerdo cuvier) [Springer, 1963; Randall, 1967; Tricas et al., 1981] shark, and may be evidence of an endogenous circadian rhythm (Fig. 4). These species inhabit greater depths during the day (60-400 m and as deep as $600 \mathrm{~m}$ in some species) than during the night (surface to $100 \mathrm{~m}$ ) (although Gleiss et al. [2013] observed the opposite pattern in whale sharks) and engage in DVMs at dusk and dawn. Descents and ascents do not appear to involve "fly-glide" behaviour (rapid ascents, 
Fig. 4. Example of DVMs in a ram ventilating shark. DVMs of a bigeye thresher shark across 4 days. DVM data are superimposed on a $1{ }^{\circ} \mathrm{C}$ isotherm plot produced from expendable bathythermograph casts. Dark photoperiods are indicated by black, bold lines along the top, horizontal axis. Reprinted from Nakano et al. [2003], with permission from Inter-Research Science Publisher.

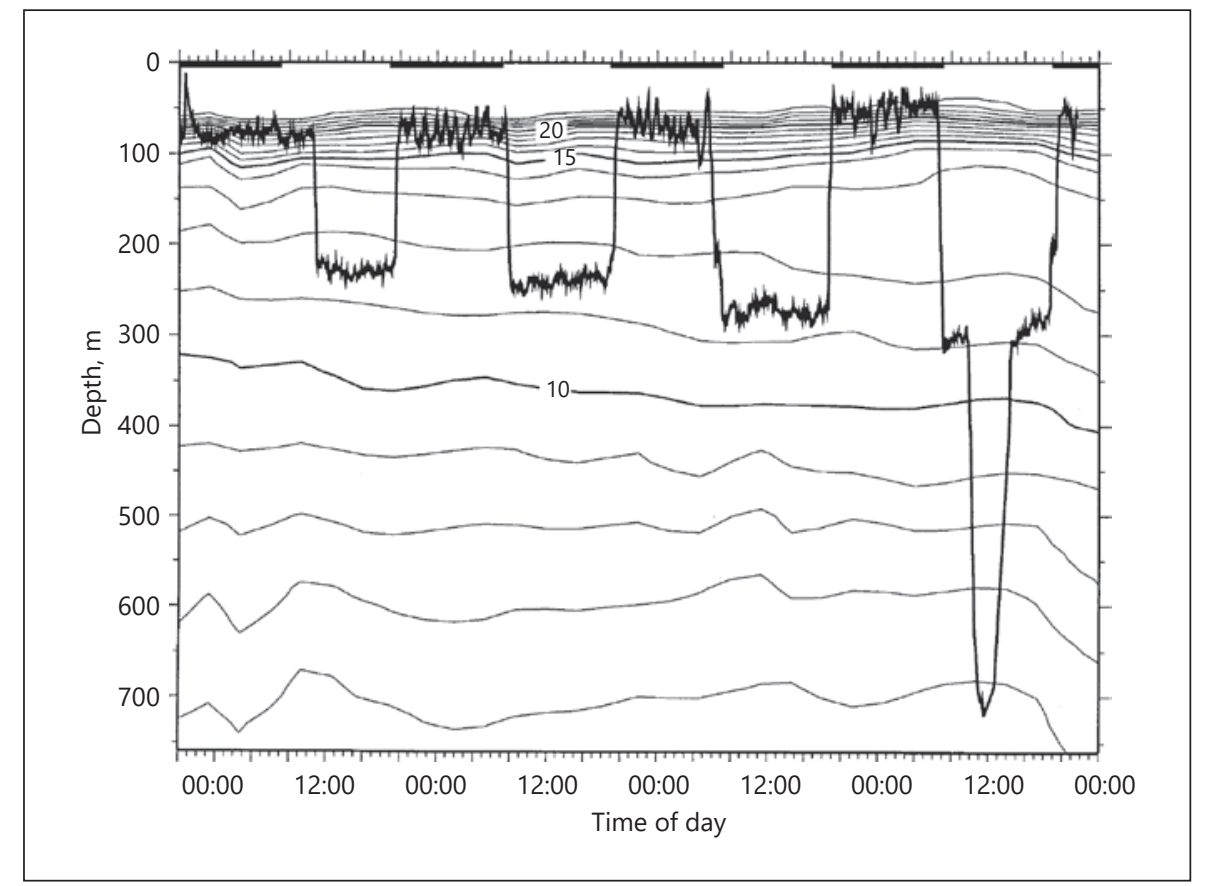

Wild scalloped hammerhead sharks (Sphyrna lewini) gather around a seamount, maintaining a state of relatively low activity during the day, during which time they do not feed, even in the presence of suitable prey. At night, the hammerheads disperse to hunt and feed [Klimley and Nelson, 1984; Klimley et al., 1988]. In the wild, hammerhead pups engage in diurnal refuging behaviour and remain in murky bay water during the day, while venturing out onto reefs to forage at night [Clarke, 1971; Holland et al., 1992; Holland et al., 1993]. Conversely, captive bonnethead sharks (S. tiburo) "patrol" throughout the day, and swimming levels (speed and distance covered) decrease at night [Myrberg and Gruber, 1974], although daytime activity may be influenced by daytime feeding. As with buccal pumping sharks and rays discussed above, there have been no systematic sleep studies on any ram ventilating fish. Owing to the absence of comprehensive sleep data on elasmobranchs, we consider next what form sleep could take in these largely unstudied animals.

\section{Hypothesis: Buccal Pumping Sharks and Rays Sleep, Ram Ventilating Fishes Do Not}

It has been suggested that buccal pumping sharks and rays sleep, an ability afforded to them by extended periods of restfulness [Compagno, 1988], but that ram ventilating fishes have secondarily lost the need for sleep, due to their
Kelly/Collin/Hemmi/Lesku 
Fig. 5. Unihemispheric non-REM sleep in a bottlenose dolphin (Tursiops truncates). Electrodes were placed over the left (1-3) and right (4-6) cortical hemispheres. The left hemisphere shows an awake EEG (red) while the other hemisphere concurrently shows the high amplitude, slow waves of non-REM sleep (blue). Modified from Mukhametov et al. [1977], with permission from Elsevier.

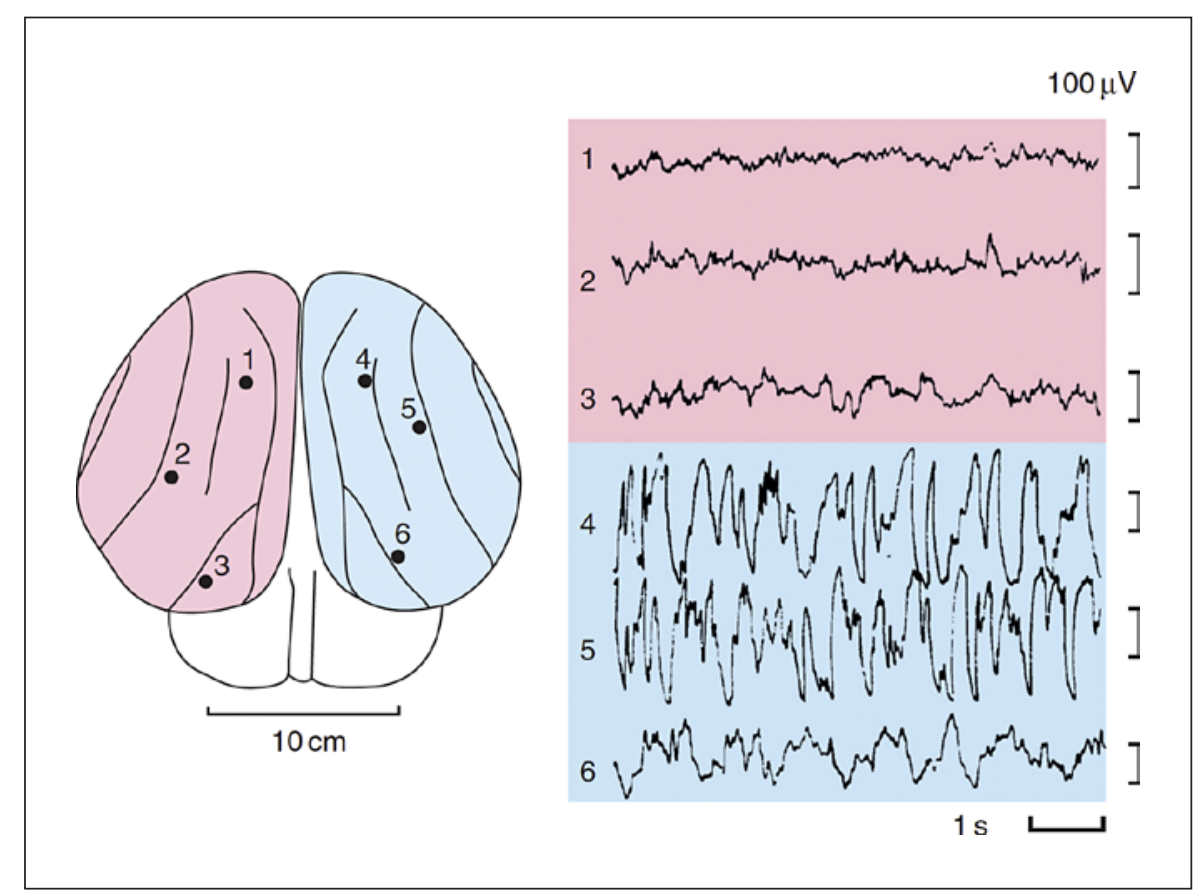

continuously swimming lifestyle [Kavanau, 1998]. This hypothesis may have stemmed from the fact that animals living in more simplified environments have independently evolved reductions in the amount of sleep, including in cave-living fishes [Duboué et al., 2011; Yoshizawa et al., 2015] and subterranean mole rats [Kruger et al., 2016]. The sensory-impoverished environment of cavefishes and fossorial rats might foster reduced brain use during wakefulness, thereby reducing the need for sleep. This argument led Kavanau to suggest that obligate ram ventilating sharks might not sleep at all, owing to the reduced visual input experienced for the majority of their lives in open, barren seascapes [Kavanau, 1998].

In our view, the possibility that ram ventilating sharks and rays do not sleep, seems unlikely. Many species of shark, including pelagic species, are known to have excellent visual capabilities [Sabbah et al., 2010; Collin, 2018], playing a role in predatory behaviour, orientation and navigation [Lisney et al., 2012], communication, and social behaviour [Hart et al., 2006]. Moreover, at least some species of sharks show complex learning, similar to that observed in teleost fishes [Fuss et al., 2014].

Importantly, the evolutionary persistence of sleep also makes it unlikely that only some species of shark and ray would have secondarily lost the need for sleep. Sleep is widespread across animals [Lesku et al., 2019], having been found in all species studied by sleep researchers, including several species of arthropods and molluscs, and even roundworms, flatworms, and jellyfish [Lesku and Ly, 2017; Nath et al., 2017; Omond et al., 2017]. Furthermore, species that routinely sleep little [Ruckebusch, 1972; Gravett et al., 2017] or hardly sleep at all when their ecology demands sustained waking performance [Lesku et al., 2012; Rattenborg et al., 2016], still sleep. Even animals experiencing a heightened risk of predation [Lima et al., 2005], as well as flying birds [Rattenborg et al., 2016, 2019], swimming mammals [Lyamin et al., 2008, 2016], and humans driving motor vehicles [often to unproductive ends; Tefft, 2018], all sleep. The remarkable evolutionary (and ecological) longevity of sleep indicates that it must serve some ancient and important function. Consequently, ram ventilating sharks and rays likely also sleep. What form might that sleep take?

\section{Hypothesis: Buccal Pumping Sharks and Rays Sleep Bihemispherically, Ram Ventilating Fishes Sleep Unihemispherically}

In the earliest known study on sleep in sharks, Weber [1961] commented that while not all fishes display conspicuous behavioural changes between day and night, such animals might instead sleep while swimming. Similar to ram ventilating sharks and rays, many marine mammals also swim continuously, and yet sleep. In terrestrial mammals, non-REM sleep is accompanied by an almost 
complete behavioural shutdown while slow waves occur in both cerebral hemispheres. Conversely, cetaceans swim while sleeping with one-half of their brain at a time, or unihemispherically (Fig. 5). Unihemispheric nonREM sleep is the main form of sleep in cetaceans, and each hemisphere is independently capable of showing wake-related or non-REM sleep EEG activity. During unihemispheric sleep, the eye neurologically connected to the hemisphere showing slow waves is typically closed, while the other eye remains open. Cetaceans use the open eye to visually monitor the local environment [Goley et al., 1999; Sekiguchi et al., 2006]. In this way, cetaceans, and perhaps some sharks and rays, can obtain the benefits of sleep while swimming.

Other marine mammals, including otariid seals, walruses, and manatees [Lyamin et al., 2008], are also capable of generating interhemispheric differences in brain activity during sleep. Interestingly, in seals there are phylogenetic and respiratory differences that might have relevance to understanding how buccal pumping and ram ventilating sharks and rays obtain a daily amount of sleep. Earless seals (family Phocidae) retain the bihemispheric non-REM sleep patterns of their terrestrial ancestors, even when sleeping in seawater. However, eared seals (family Otariidae) sleep predominantly bihemispherically while on land but exhibit more asymmetric (more cetacean-like) non-REM sleep in the water [Lyamin et al., 2016]. Otariid seals use this interhemispheric asymmetry to keep their nares above the surface of the water to breathe. The flipper neurologically connected to the more awake hemisphere remains in the water, paddling slowly, while the other flipper is motionless. This interesting situation between the sleep patterns of phocid and otariid seals raises the possibility that buccal pumping sharks and rays might retain a bihemispheric form of sleep, whereas ram ventilating sharks and rays might have evolved the ability to sleep unihemispherically. By advancing this idea, we do not mean to suggest that sharks and rays engage in non-REM sleep per se, but rather that one hemisphere might show a shark sleeprelated EEG pattern, while the other shows the signature of wakefulness.

Instead of sleeping with an interhemispheric difference in brain state in the case of unihemispheric sleep, sharks and rays might sleep with an intrahemispheric difference in brain activity. In humans and rats, sleep and wake-like brain activity can occur simultaneously in different parts of the brain in an outwardly sleeping animal [Nir et al., 2011; Nobili et al., 2011; Vyazovskiy et al., 2011]. In humans with epilepsy who have been implant- ed with deep brain electrodes for chronic recordings, the motor cortex appears to reveal wake-like activity, while the dorsolateral prefrontal cortex exhibits non-REM sleep [Nobili et al., 2011]. As non-REM sleep accrues across the night (and the need for sleep diminishes), the occurrence of "local wakefulness" increases. Similar results have been found in recordings of the healthy rat brain [Vyazovskiy et al., 2011], indicating that this phenomenon in humans is unrelated to epilepsy, but rather reflects a general feature of the mammalian brain. This mix of wake and sleep EEG activity might provide clues to how sharks and rays sleep. Interestingly, a small group of neurons control the lateral movements of the tail to maintain forward propulsion in bony fishes [Thiele et al., 2014]. If this were true in sharks and rays, then they might sleep in a piecemeal manner, wherein much of the telencephalon can sleep, while the few pathways that control the tail remain awake. Of course, it is also possible that all sharks and rays sleep with their whole-brain at a time, but ventilate passively using favourable water currents.

\section{Hypothesis: Ram Ventilating Fishes Sleep in Currents}

It is possible that currents play a role in permitting restfulness and sleep in ram ventilating sharks and rays. Animals facing into currents would have oxygenated water passively pushed over their gills facilitating respiration and allowing the animals to remain motionless or maintain a low level of, or indeed no, swimming activity. This may explain reports of normally obligate ram ventilating sharks resting on the seafloor off the coast of Mexico [Clark, 1973]. It was reported by local divers that strong currents could be felt at the times when large numbers of sharks were found to be inactive; however, the orientation of the sharks relative to the direction of the current was not reported. Furthermore, the sharks were observed passively pumping water over their gills rather than allowing the current to passively do so. Klimley and Nelson [1984] found no evidence that milling hammerheads changed their position or swimming direction at a seamount in response to changes in current direction. Similarly, Carey et al. [1990] reported that blue sharks did not swim against currents when recording their vertical and horizontal movements in the water column. To our knowledge, no other observations have been reported regarding inactivity in ram ventilating sharks associated with currents. Hence, although plausible, this idea requires further investigation.
Kelly/Collin/Hemmi/Lesku 


\section{Conclusion}

For a taxon of vertebrates consisting of over 1,000 species, studies on only 33 species of sharks, and on a single ray, contain data potentially related to sleep. Furthermore, no single study has focused specifically and comprehensively on sleep, but rather often on the circadian organisation of swimming or anecdotes about responsiveness to stimulation. It is also clear that the fundamental biology of elasmobranchs is poorly understood. Specifically, the degree to which buccal pumping and ram ventilating sharks and rays exist as distinct categories is unclear. Some species thought to be obligate swimmers can show reduced activity, or even become inactive for short periods of time by switching their mode of ventilation. Thus, more research is needed to understand how many species are in fact obligate constant swimmers, and when and why swimming sharks and rays become quiescent. Furthermore, it remains unknown whether extensive periods of restfulness in buccal pumping sharks and rays can be considered sleep or simply quiet wakefulness. Unfortunately, none of the studies covered in this review answer these questions. To do so, future work must include a systematic investigation into the presence or absence of sleep, preferably on a broad range of elasmobranchs. This would include investigating the persistence of circadian activity patterns in both buccal pumping and obligate swimming species, along with measuring arousal thresholds, and testing for the homeostatic regulation of restfulness to distinguish sleep from quiet wakefulness in sedentary species. The inclusion of other measurements, such as respiration rates, oxygen consumption, and heart rate also should be included in any description of sleep in sharks and rays. Finally, there has never been a study investigating sleep/wake changes in EEG activity in cartilaginous fishes. Identifying sleep using measures of brain activity is the most reliable method available, as behaviour alone can sometimes be misleading, or at least, incomplete [Aulsebrook et al., 2016]. Among living vertebrates, sharks and rays best resemble the earliest jawed vertebrates, and so describing sleep in these animals may provide new insight into the evolution of sleep in other, more derived vertebrates.

\section{Acknowledgements}

We are grateful to the American Society of Ichthyologists and Herpetologists, Inter-Research Science Publisher, and Elsevier for granting the republication of material.

\section{Disclosure Statement}

The authors have no conflicts of interest to declare.

\section{Funding Sources}

This review was supported by The University of Western Australia and by La Trobe University.

\section{Author Contributions}

M.L.K. and J.A.L. wrote the first draft; all authors then contributed to editing the manuscript.

\section{References}

Andrews KS, Williams GD, Farrer D, Tolimieri N, Harvey CJ, Bargmann G, et al. Diel activity patterns of sixgill sharks, Hexanchus griseus: the ups and downs of an apex predator. Anim Behav. 2009;78(2):525-36.

Appelbaum L, Wang GX, Maro GS, Mori R, Tovin A, Marin W, et al. Sleep-wake regulation and hypocretin-melatonin interaction in zebrafish. Proc Natl Acad Sci USA. 2009 Dec; 106(51):21942-7.

Árnason BB, Porsteinsson H, Karlsson KÆ. Absence of rapid eye movements during sleep in adult zebrafish. Behav Brain Res. 2015 Sep; 291:189-94.

Aserinsky E, Kleitman N. Regularly occurring periods of eye motility, and concomitant phenomena, during sleep. Science. 1953 Sep; 118(3062):273-4.
Aulsebrook AE, Jones TM, Rattenborg NC, Roth TC 2nd, Lesku JA. Sleep ecophysiology: integrating neuroscience and ecology. Trends Ecol Evol. 2016 Aug;31(8):590-9.

Barker SM, Peddemors VM, Williamson JE. A video and photographic study of aggregation, swimming and respiratory behaviour changes in the Grey Nurse Shark (Carcharias taurus) in response to the presence of SCUBA divers. Mar Freshwat Behav Physiol. 2011;44(2):7592.

Barnett A, Payne NL, Semmens JM, Fitzpatrick R. Ecotourism increases the field metabolic rate of whitetip reef sharks. Biol Conserv. 2016; 199:132-6.

Borbély AA. A two process model of sleep regulation. Hum Neurobiol. 1982;1(3):195-204.
Brett JR, Blackburn JM. Metabolic rate and energy expenditure of the spinydogfish, Squalus acanthias. J Fish Res Board Can. 1978;35(6): 816-21.

Brown CE, Muir BS. Analysis of ram ventilation of fish gills with application to skipjack tuna (Katsuwonus pelamis). J Fish Res Board Can. 1970;27(9):1637-52.

Bruce BD, Bradford RW. The effects of shark cage-diving operations on the behaviour and movements of white sharks, Carcharodon carcharias, at the Neptune Islands, South Australia. Mar Biol. 2013;160(4):889-907.

Budker P. The life of sharks. New York: Columbia University Press; 1971.

Campbell SS, Tobler I. Animal sleep: a review of sleep duration across phylogeny. Neurosci Biobehav Rev. 1984;8(3):269-300. 
Carey F, Kanwisher J, Brazier O, Gabrielson G, Casey J, Pratt H Jr. Temperature and activities of a white shark. Carcharodon carcharias. Copeia. 1982;1982(2):254-60.

Carey F, Scharold J, Kalmijn AJ. Movements of blue sharks (Prionace glauca) in depth and course. Mar Biol. 1990;106(3):329-42.

Carey FG, Teal JM, Kanwisher JW. The visceral temperatures of mackerel sharks (Lamnidae). Physiol Zool. 1981;54(3):334-44.

Carlson J, Goldman K, Lowe C. Metabolism, energetic demand, and endothermy. In: Carrier JC, Musick JA, Heithaus MR, editors. Biology of sharks and their relatives. CRC Mar Biol Series. Volume 1. Boca Raton: CRC Press; 2004. pp. 203-24.

Carlson JK, Parsons GR. The effects of hypoxia on three sympatric shark species: physiological and behavioral responses. Environ Biol Fishes. 2001;61(4):427-33.

Casterlin ME, Reynolds WW. Diel activity patterns of the smooth dogfish shark, Mustelus canis. Bull Mar Sci. 1979;29(3):440-2.

Chapman DD, Pikitch EK, Babcock EA, Shivji MS. Deep-diving and diel changes in vertical habitat use by Caribbean reef sharks Carcharhinus perezi. Mar Ecol Prog Ser. 2007;344: 271-5.

Clark E. Sleeping sharks in Mexico. Underwat Nat. 1973;8:4-7.

Clark E, Kristof E. Deep-sea elasmobranchs observed from submersibles off Bermuda, Grand Cayman, and Freeport, Bahamas. In: Pratt HL Jr, Gruber SH, Taniuchi T, editors. Elasmobranchs as living resources: advances in the biology, ecology, systematics, and the status of fisheries. Volume 90. Seattle: NOAA Tech Rep NMFS; 1990. pp. 269-84.

Clarke C, Lea J, Ormond R. Reef-use and residency patterns of a baited population of silky sharks, Carcharhinus falciformis, in the Red Sea. Mar Freshw Res. 2011;62(6):668-75.

Clarke TA. The ecology of the scalloped hammerhead shark, Sphyrna lewini, in Hawaii. Pac Sci. 1971;25:133-44.

Collin SP. Scene through the eyes of an apex predator: a comparative analysis of the shark visual system. Clin Exp Optom. 2018 Sep; 101(5):624-40.

Compagno LJ. Sharks of the order Carcharhiniformes. New Jersey: The Blackburn Press; 1988.

Compagno LJ. Systematics and body form. In: Hamlett WC, editor. Sharks, skates and rays: the biology of elasmobranch fishes. Volume 1. Baltimore: John Hopkins University Press; 1999. pp. 1-42.

Cortés E, Gruber SH. Diet, feeding habits and estimates of daily ration of young lemon sharks, Negaprion brevirostris (Poey). Copeia. 1990; 1990(1):204-18.

Dubin RE, Baker JD. Two types of cover-seeking behavior at sunset by the princess parrotfish, Scarus taeniopterus, at Barbados, West Indies. Bull Mar Sci. 1982;32(2):572-83.
Duboué ER, Borowsky RL, Keene AC. $\beta$-adrenergic signaling regulates evolutionarily derived sleep loss in the Mexican cavefish. Brain Behav Evol. 2012;80(4):233-43.

Duboué ER, Keene AC, Borowsky RL. Evolutionary convergence on sleep loss in cavefish populations. Curr Biol. 2011 Apr;21(8):671-6.

Dudgeon CL, Lanyon JM, Semmens JM. Seasonality and site fidelity of the zebra shark, Stegostoma fasciatum, in southeast Queensland, Australia. Anim Behav. 2013; 85(2):471-81.

Ebert DA. Observations on the predatory behaviour of the sevengill shark Notorynchus cepedianus. S Afr J Mar Sci. 1991;11(1):455-65.

Enger PS. The electroencephalogram of the codfish (Gadus callarias). Acta Physiol Scand. 1957 Apr;39(1):55-72.

Falcón J, Besseau L, Sauzet S, Boeuf G. Melatonin effects on the hypothalamo-pituitary axis in fish. Trends Endocrinol Metab. 2007 Mar; 18(2):81-8

Finstad WO, Nelson DR. Circadian activity rhythm in the horn shark, Heterodontus francisci: effect of light intensity. Bull South Calif Acad Sci. 1975;74(1):20-6.

Fitzpatrick R, Abrantes KG, Seymour J, Barnett A. Variation in depth of whitetip reef sharks: does provisioning ecotourism change their behaviour? Coral Reefs. 2011;30(3):569-77.

Fuss T, Bleckmann H, Schluessel V. Visual discrimination abilities in the gray bamboo shark (Chiloscyllium griseum). Zoology (Jena). 2014 Apr;117(2):104-11.

Gleiss AC, Gruber SH, Wilson RP. Multi-channel data-logging: towards determination of behaviour and metabolic rate in free-swimming sharks. In: Nielsen JL, Arrizabalaga H, Fragoso N, Hobday A, Lutcavage M, Sibert J, editors. Tagging and tracking of marine animals with electronic devices. New York: Springer; 2009. pp. 211-28.

Gleiss AC, Wright S, Liebsch N, Wilson RP, Norman B. Contrasting diel patterns in vertical movement and locomotor activity of whale sharks at Ningaloo Reef. Mar Biol. 2013; 160(11):2981-92.

Goldshmid R, Holzman R, Weihs D, Genin A Aeration of corals by sleep-swimming fish. Limnol Oceanogr. 2004;49(5):1832-9.

Goley PD. Behavioral aspects of sleep in pacific white-sided dolphins (Lagenorhynchus obliquidens, Gill 1865) 1. Mar Mamm Sci. 1999;15(4):1054-64.

Graeber RC, Ebbesson SO. Visual discrimination learning in normal and tectal-ablated nurse sharks (Ginglymostoma cirratum). Comp Biochem Physiol A Comp Physiol. 1972 May; 42(1):131-9.

Gravett N, Bhagwandin A, Sutcliffe R, Landen K, Chase MJ, Lyamin OI, et al. Inactivity/sleep in two wild free-roaming African elephant matriarchs - Does large body size make elephants the shortest mammalian sleepers? PLoS One. 2017 Mar;12(3):e0171903.
Gruber SH, Nelson DR, Morrissey JF. Patterns of activity and space utilization of lemon sharks, Negaprion brevirostris, in a shallow Bahamian lagoon. Bull Mar Sci. 1988;43(1):61-76.

Hart NS, Lisney TJ, Collin SP. Visual communication in elasmobranchs. In: Ladich F, Collin SP, Moller P, Kapoor BG, editors. Communication in fishes. Plymouth: Science Publishers; 2006. pp. 337-92.

Hartse KM. The phylogeny of sleep. Handb Clin Neurol. 2011;98:97-109.

Heithaus M, Dill L, Marshall G, Buhleier B. Habitat use and foraging behavior of tiger sharks (Galeocerdo cuvier) in a seagrass ecosystem. Mar Biol. 2002;140(2):237-48.

Holland K, Lowe C, Peterson J, Gill A. Tracking coastal sharks with small boats: hammerhead shark pups as a case study. Mar Freshw Res. 1992;43(1):61-6.

Holland KN, Wetherbee BM, Peterson JD, Lowe CG. Movements and distribution of hammerhead shark pups on their natal grounds. Copeia. 1993;1993(2):495-502.

Holts D, Bedford DW. Horizontal and vertical movements of the shortfin mako shark, Isurus oxyrinchus, in the Southern California Bight. Mar Freshw Res. 1993;44(6):901-9.

Huber R, Ghilardi MF, Massimini M, Ferrarelli F, Riedner BA, Peterson MJ, et al. Arm immobilization causes cortical plastic changes and locally decreases sleep slow wave activity. Nat Neurosci. 2006 Sep;9(9):1169-76.

Hur SP, Takeuchi Y, Itoh H, Uchimura M, Takahashi K, Kang HC, et al. Fish sleeping under sandy bottom: interplay of melatonin and clock genes. Gen Comp Endocrinol. 2012 May;177(1):37-45.

Iglesias TL, Boal JG, Frank MG, Zeil J, Hanlon RT. Cyclic nature of the REM sleep-like state in the cuttlefish Sepia officinalis. J Exp Biol. 2019 Jan;222(Pt 1):jeb174862.

Iigo M, Tabata M. Circadian rhythms of locomotor activity in the goldfish Carassius auratus. Physiol Behav. 1996 Sep;60(3):775-81.

Jaggard J, Robinson BG, Stahl BA, Oh I, Masek P, Yoshizawa $\mathrm{M}$, et al. The lateral line confers evolutionarily derived sleep loss in the Mexican cavefish. J Exp Biol. 2017 Jan;220(Pt 2): 284-93.

Jaggard JB, Stahl BA, Lloyd E, Prober DA, Duboué ER, Keene AC. Hypocretin underlies the evolution of sleep loss in the Mexican cavefish. eLife. 2018 Feb;7:e32637.

Jouvet M, Michel F, Courjon J. Sur un stade d'activite electrique cerebrale rapide au tours du sommeil physiologique. C R Seanc Sot Biol. 1959;153:101-5.

Karmanova H, Belich A. Temporal organization of "wakefulness-primary sleep" cycle in the dwarf catfish Ictalurus nebulosus. J Evol Biochem Physiol. 1983;19:131-6.

Karmanova I, Belich A, Lazarev S. An electrophysiological study of wakefulness and sleeplike states in fish and amphibians. In: Laming $\mathrm{PR}$, editor. Brain mechanisms of behaviour in lower vertebrates. Cambridge: Cambridge University Press; 1981. pp. 181-202. 
Karmanova IG, Titkov ES, Popova DI. [Species characteristics of the diurnal periodicity of rest and activity in Black Sea fish]. Zh Evol Biokhim Fiziol. 1976 Sep-Oct;12(5):486-8. Russian.

Kavanau JL. Vertebrates that never sleep: implications for sleep's basic function. Brain Res Bull. 1998 Jul;46(4):269-79.

Kazimi N, Cahill GM. Development of a circadian melatonin rhythm in embryonic zebrafish. Brain Res Dev Brain Res. 1999 Oct;117(1): $47-52$.

Klimley A, Butler S, Nelson D, Stull A. Diel movements of scalloped hammerhead sharks, Sphyrna lewini Griffith and Smith, to and from a seamount in the Gulf of California. J Fish Biol. 1988;33(5):751-61.

Klimley AP, Nelson DR. Diel movement patterns of the scalloped hammerhead shark (Sphyrna lewini) in relation to El Bajo Espiritu Santo: a refuging central-position social system. Behav Ecol Sociobiol. 1984;15(1):45-54.

Kruger JL, Gravett N, Bhagwandin A, Bennett NC, Archer EK, Manger PR. Sleep in the Cape mole rat: a short-sleeping subterranean rodent. Brain Behav Evol. 2016;87(2):78-87.

Lesku JA, Aulsebrook AE, Kelly ML, Tisdale RK. Evolution of sleep and adaptive sleeplessness. In: Dringenberg HC, editor. Handbook of sleep research. Cambridge: Academic Press/ Elsevier; 2019. https://doi.org/10.1016/B9780-12-813743-7.00020-7.

Lesku JA, Ly LM. Sleep origins: restful jellyfish are sleeping jellyfish. Curr Biol. 2017 Oct; 27(19):R1060-2.

Lesku JA, Rattenborg NC, Valcu M, Vyssotski AL, Kuhn S, Kuemmeth F, et al. Adaptive sleep loss in polygynous pectoral sandpipers. Science. 2012 Sep;337(6102):1654-8.

Lesku JA, Vyssotski AL, Martinez-Gonzalez D, Wilzeck C, Rattenborg NC. Local sleep homeostasis in the avian brain: convergence of sleep function in mammals and birds? Proc Biol Sci. 2011 Aug;278(1717):2419-28.

Leung LC, Wang GX, Madelaine R, Skariah G, Kawakami K, Deisseroth K, et al. Neural signatures of sleep in zebrafish. Nature. $2019 \mathrm{Jul}$; 571(7764):198-204.

Libourel PA, Barrillot B, Arthaud S, Massot B, Morel AL, Beuf O, et al. Partial homologies between sleep states in lizards, mammals, and birds suggest a complex evolution of sleep states in amniotes. PLoS Biol. 2018 Oct; 16(10):e2005982.

Lima SL, Rattenborg NC, Lesku JA, Amlaner CJ. Sleeping under the risk of predation. Anim Behav. 2005;70(4):723-36.

Lisney TJ, Theiss SM, Collin SP, Hart NS. Vision in elasmobranchs and their relatives: 21st century advances. J Fish Biol. 2012 Apr;80(5): 2024-54.

Lyamin OI, Lapierre JL, Kosenko PO, Kodama T, Bhagwandin A, Korneva SM, et al. Monoamine release during unihemispheric sleep and unihemispheric waking in the fur seal. Sleep (Basel). 2016 Mar;39(3):625-36.
Lyamin OI, Manger PR, Ridgway SH, Mukhametov LM, Siegel JM. Cetacean sleep: an unusual form of mammalian sleep. Neurosci Biobehav Rev. 2008 Oct;32(8):1451-84.

McKibben JN, Nelson DR. Patterns of movement and grouping of gray reef sharks, Carcharhinus amblyrhynchos, at Enewetak, Marshall Islands. Bull Mar Sci. 1986;38(1):89-110.

McLaughlin R, O'Gower A. Life history and underwater studies of a heterodont shark. Ecol Monogr. 1971;41(4):271-89.

Meffert P. Ultrasonic recorder for locomotor activity studies. Trans Am Fish Soc. 1968;97(1) $12-7$

Metcalfe JD, Butler PJ. Changes in activity and ventilation in response to hypoxia in unrestrained, unoperated dogfish (Scyliorhinus canicula L.). J Exp Biol. 1984 Jan;108(1):4118.

Morrissey JF, Gruber SH. Home range of juvenile lemon sharks, Negaprion brevirostris. Copeia. 1993;1993(2):425-34.

Mukhametov LM, Supin AY, Polyakova IG. Interhemispheric asymmetry of the electroencephalographic sleep patterns in dolphins. Brain Res. 1977 Oct;134(3):581-4.

Myrberg AA Jr, Gruber SH. The behavior of the bonnethead shark, Sphyrna tiburo. Copeia. 1974;1974(2):358-74.

Nakano H, Matsunaga H, Okamoto H, Okazaki M. Acoustic tracking of bigeye thresher shark Alopias superciliosus in the eastern Pacific Ocean. Mar Ecol Prog Ser. 2003;265:255-61.

Nath RD, Bedbrook CN, Abrams MJ, Basinger T, Bois JS, Prober DA, et al. The jellyfish Cassiopea exhibits a sleep-like state. Curr Biol. 2017 Oct;27(19):2984-2990.e3.

Nelson D, Johnson RH. Diel activity rhythms in the nocturnal, bottom-dwelling sharks, Heterodontus francisci and Cephaloscyllium ventriosum. Copeia. 1970;1970(4):732-9.

Nelson D, Johnson R. Behavior of the reef sharks of Rangiroa, French Polynesia. Nat Geo Res Rep. 1980;12:479-99.

Nelson DR, McKibben JN, Strong WR Jr, Lowe CG, Sisneros JA, Schroeder DM, et al. An acoustic tracking of a megamouth shark, Megachasma pelagios: a crepuscular vertical migrator. Environ Biol Fishes. 1997;49(4): 389-99.

Nir Y, Staba RJ, Andrillon T, Vyazovskiy VV, Cirelli C, Fried I, et al. Regional slow waves and spindles in human sleep. Neuron. 2011 Apr; 70(1):153-69.

Nixon AJ, Gruber SH. Diel metabolic and activity patterns of the lemon shark (Negaprion brevirostris). J Exp Zool A Comp. Exp Biol. 1988; 248(1):1-6.

Nobili L, Ferrara M, Moroni F, De Gennaro L, Russo GL, Campus C, et al. Dissociated wakelike and sleep-like electro-cortical activity during sleep. Neuroimage Clin. 2011;58(2): 612-9.
Omond S, Ly LM, Beaton R, Storm JJ, Hale MW, Lesku JA. Inactivity is nycthemeral, endogenously generated, homeostatically regulated, and melatonin modulated in a free-living platyhelminth flatworm. Sleep (Basel). 2017 Oct; 40(10): https://doi.org/10.1093/sleep/ zsx124.

Papastamatiou YP, Wetherbee BM, O'Sullivan J, Goodmanlowe GD, Lowe CG. Foraging ecology of cookiecutter sharks (Isistius brasiliensis) on pelagic fishes in Hawaii, inferred from prey bite wounds. Environ Biol Fishes. 2010; 88(4):361-8.

Pavan C. Observations and experiments on the cave fish Pimelodella kronei and its relatives. Am Nat. 1946 May-Jun;80(792):343-61.

Peyrethon J, Dusan-Peyrethon D. Etude polygraphique du cycle veille-sommeil d'un téléostéen (Tinca tinca). C R Seances Soc Biol Fil. 1967;161(12):2533-7.

Pinheiro-da-Silva J, Tran S, Luchiari AC. Sleep deprivation impairs cognitive performance in zebrafish: a matter of fact? Behav Processes. 2018 Dec;157:656-63.

Pollard D, Lincoln Smith M, Smith A. The biology and conservation status of the grey nurse shark (Carcharias taurus Rafinesque 1810) in New South Wales, Australia. Aquat Conserv. 1996;6(1):1-20.

Randall JE. Food habits of reef fishes of the West Indies. Stud Trop Oceanogr. 1967;5:665-847.

Randall JE. Contribution to the biology of the whitetipreef shark (Triaenodon obesus). Pac Sci. 1977;31:143-64.

Rattenborg NC, van der Meij J, Beckers GJ, Lesku JA. Local aspects of avian non-REM sleep. Front Neurosci. 2019 Jun;13:567.

Rattenborg NC, Voirin B, Cruz SM, Tisdale R, Dell'Omo G, Lipp HP, et al. Evidence that birds sleep in mid-flight. Nat Commun. 2016 Aug;7(1):12468.

Roberts JL. Ram gill ventilation in fishes. In: Sharp GD, Dizon AE, editors. The physiological ecology of tunas. Volume 1. Ney York: Academic Press; 1978. pp. 83-8.

Rowat D, Meekan M, Engelhardt U, Pardigon B, Vely M. Aggregations of juvenile whale sharks (Rhincodon typus) in the Gulf of Tadjoura, Djibouti. Environ Biol Fishes. 2007;80(4): 465-72.

Ruckebusch Y. The relevance of drowsiness in the circadian cycle of farm animals. Anim Behav. 1972 Nov;20(4):637-43.

Ryder R. Effects of ambient light variations on behavior of yearling, subadult, and adult walleyes (Stizostedion vitreum vitreum). J Fish Res Board Can. 1977;34(10):1481-91.

Sabbah S, Laria RL, Gray SM, Hawryshyn CW. Functional diversity in the color vision of cichlid fishes. BMC Biol. 2010 Oct;8(1):133.

Scariotta T, Nelson D. Diel behaviour of the blue shark, Prionace glauca, near Santa Catalina Island. Calif. Fish Bull. 1977;75:519-28.

Sekiguchi Y, Arai K, Kohshima S. Sleep behaviour: sleep in continuously active dolphins. Nature. 2006 Jun;441(7096):E9-10. 
Shapiro CM, Hepburn HR. Sleep in a schooling fish, Tilapia mossambica. Physiol Behav. 1976 May;16(5):613-5.

Shein-Idelson M, Ondracek JM, Liaw HP, Reiter $S$, Laurent G. Slow waves, sharp waves, ripples, and REM in sleeping dragons. Science. 2016 Apr;352(6285):590-5.

Shepard EL, Ahmed MZ, Southall EJ, Witt MJ, Metcalfe JD, Sims DW. Diel and tidal rhythms in diving behaviour of pelagic sharks identified by signal processing of archival tagging data. Mar Ecol Prog Ser. 2006;328:205-13.

Siegel JM. Rapid eye movement sleep. In: Kryger M, Roth T, Dement WC, editors. Principles and practices of sleep mechanisms. Philadelphia: WB Saunders; 2016. pp. 78-95.

Sigurgeirsson B, Thornorsteinsson H, Sigmundsdóttir S, Lieder R, Sveinsdóttir HS, Sigurjónsson ÓE, et al. Sleep-wake dynamics under extended light and extended dark conditions in adult zebrafish. Behav Brain Res. 2013 Nov; 256:377-90.

Sims D, Davies S, Bone Q. On the diel rhythms in metabolism and activity of post-hatching lesser spotted dogfish, Scyliorhinus canicula. J Fish Biol. 1993;43(5):749-54.

Sims D, Nash J, Morritt D. Movements and activity of male and female dogfish in a tidal sea lough: alternative behavioural strategies and apparent sexual segregation. Mar Biol. 2001; 139(6):1165-75.

Sims DW, Southall EJ, Tarling GA, Metcalfe JD. Habitat-specific normal and reverse diel vertical migration in the plankton-feeding basking shark. J Anim Ecol. 2005;74(4):755-61.

Sims DW, Wearmouth VJ, Southall EJ, Hill JM, Moore P, Rawlinson K, et al. Hunt warm, rest cool: bioenergetic strategy underlying diel vertical migration of a benthic shark. J Anim Ecol. 2006 Jan;75(1):176-90.

Singh C, Rihel J, Prober DA. Neuropeptide Y regulates sleep by modulating noradrenergic signaling. Curr Biol. 2017 Dec;27(24):3796-3811.e5.

Smith K, Scarr M, Scarpaci C. Grey nurse shark (Carcharias taurus) diving tourism: tourist compliance and shark behaviour at Fish Rock, Australia. Environ Manage. 2010 Nov;46(5): 699-710.

Springer S. Field observations on large sharks of the Florida-Caribbean region. In: Gilbert PW, editor. Sharks and survival. Boston: Heath and Co.; 1963. pp. 95-113.

Standora EA, Nelson DR. A telemetric study of the behavior of free-swimming Pacific angel sharks, Squatina californica. Bull South Calif Acad Sci. 1977;76(3):193-201.
Starck W, Davis W. Night habits of fishes of Alligator Reef, Florida. Ichthyologica. 1966; 38(4):313-56.

Stokesbury MJ, Harvey-Clark C, Gallant J, Block BA, Myers RA. Movement and environmental preferences of Greenland sharks (Somniosus microcephalus) electronically tagged in the St. Lawrence Estuary, Canada. Mar Biol. 2005;148(1):159-65.

Stopa RM, Hoshino K. Electrolocation-communication discharges of the fish Gymnotus carapo L. (Gymnotidae: Gymnotiformes) during behavioral sleep. Braz J Med Biol Res. 1999 Oct;32(10):1223-8.

Tauber E. Phylogeny of sleep. Adv Sleep Res. 1974;1:133-72.

Tauber E, Weitzman E. Eye movements during behavioral inactivity in certain Bermuda reef fish. Commun Behav Biol. 1969;3:131-5.

Tefft BC. Acute sleep deprivation and culpable motor vehicle crash involvement. Sleep (Basel). 2018 Oct;41(10): https://doi.org/10.1093/ sleep/zsy144.

Thiele TR, Donovan JC, Baier H. Descending control of swim posture by a midbrain nucleus in zebrafish. Neuron. 2014 Aug;83(3):67991.

Titkov E. Characteristics of the daily periodicity of wakefulness and rest in the brown bullhead (Ictalurus nebulosus). J Evol Biochem Physiol. 1976;12(4):305-9.

Tobler I. Phylogeny of sleep regulation. In: Kryger MH, Roth T, Dement WC, editors. Principles and practice of sleep medicine. Philadelphia: WB Saunders; 2011. pp. 112-25.

Tobler I, Borbély AA. Effect of rest deprivation on motor activity of fish. J Comp Physiol A Neuroethol Sens Neural Behav Physiol. 1985 Dec; 157(6):817-22.

Tomita T, Touma H, Murakumo K, Yanagisawa M, Yano N, Oka S, et al. Captive birth of tiger shark (Galeocerdo cuvier) reveals a shift in respiratory mode during parturition. Copeia. 2018;106(2):292-6.

Tricas TC, Taylor LR, Naftel G. Diel behavior of the tiger shark, Galeocerdo cuvier, at French Frigate Shoals, Hawaiian Islands. Copeia. 1981;1981(4):904-8

van Alphen B, Yap MH, Kirszenblat L, Kottler B, van Swinderen B. A dynamic deep sleep stage in Drosophila. J Neurosci. 2013 Apr;33(16): 6917-27.

Videler J, Koella W, Obál F, Schulz H. Sleep under sand cover of the labrid fish Coris julis. In: Koella W, Obal F, Schulz H, Visser P, editors. Sleep. Stuttgart: Fischer; 1986. pp. 145-7.
Vyazovskiy VV, Olcese U, Hanlon EC, Nir Y, Cirelli $\mathrm{C}$, Tononi $\mathrm{G}$. Local sleep in awake rats. Nature. 2011 Apr;472(7344):443-7.

Wardle CS. Swimming activity in marine fish. In: Laverack MS, editor. Physiological adaptations of marine animals. Volume 1. Scarborough: The Co. of Biologists Ltd.; 1985. pp. 521-40.

Weber VE. Uber ruhelagen von fischen. Z Tierpsychol. 1961;18:517-33.

Weihs D. Mechanically efficient swimming techniques for fish with negative buoyancy. J Mar Res. 1973;31:194-209.

Weng KC, Block BA. Diel vertical migration of the bigeye thresher shark (Alopias superciliosus), a species possessing orbital retia mirabilia. Fish Bull. 2004;102(1):221-9.

Weng KC, O'Sullivan JB, Lowe CG, Winkler CE, Dewar H, Block BA. Movements, behavior and habitat preferences of juvenile white sharks Carcharodon carcharias in the eastern Pacific. Mar Ecol Prog Ser. 2007;338:211-24.

West GJ, Stevens JD. Archival tagging of school shark, Galeorhinus galeus, in Australia: initial results. In: Tricas TC, Gruber SH, editors. The behavior and sensory biology of elasmobranch fishes: an anthology in memory of Donald Richard Nelson. Volume 20. Dordrecht: Springer; 2001. pp. 283-98.

Whitney NM, Papastamatiou YP, Holland KN, Lowe CG. Use of an acceleration data logger to measure diel activity patterns in captive whitetip reef sharks, Triaenodon obesus. Aquat Living Resour. 2007;20(4):299-305.

Yokogawa T, Marin W, Faraco J, Pézeron G, Appelbaum L, Zhang J, et al. Characterization of sleep in zebrafish and insomnia in hypocretin receptor mutants. PLoS Biol. 2007 Oct; 5(10):e277.

Yoshizawa M, Robinson BG, Duboué ER, Masek P, Jaggard JB, O'Quin KE, et al. Distinct genetic architecture underlies the emergence of sleep loss and prey-seeking behavior in the Mexican cavefish. BMC Biol. 2015 Feb;13(1): 15.

Zafar N, Morgan E. Feeding entrains an endogenous rhythm of swimming activity in the blind Mexican cave fish. J Interdiscipl Cycle Res. 1992;23:165-6.

Zhdanova IV. Sleep and its regulation in zebrafish. Rev Neurosci. 2011;22(1):27-36.

Zhdanova IV, Wang SY, Leclair OU, Danilova NP. Melatonin promotes sleep-like state in zebrafish. Brain Res. 2001 Jun;903(1-2):263-8. 